\title{
Multiple Equilibria and Chemical Distribution of Some Bio Metals With $\beta$-Amide $\alpha$-Aminosuccinate And $\alpha$ - Aminoisoverate as Primary Ligand and 5-Methyl 2, 4 Dioxopyrimidine as Secondary Ligand
}

\author{
Ved Prakash Shukla ${ }^{1}$, Surabhi Sinha ${ }^{2}$ and Vijay Krishna ${ }^{3}$ \\ ${ }^{I}$ Department of applied sciences (chemistry) B.B.S.College of Engg. \& Tech. Allahabad-211013 \\ ${ }^{2}$ Department of applied sciences (chemistry) United College of Engg. \& Research,Allahabad, \\ ${ }^{3}$ Department of Chemistry, University of Allahabad, Allahabad-211002,
}

\begin{abstract}
Solution Chemistry of some bivalent metal ions (viz. $\mathrm{Co}^{I I}, \mathrm{Ni}^{I I}, \mathrm{Cu}^{I I}, \mathrm{Zn}^{I I}$ ) with $\beta$-amide $\alpha$ aminosuccinate (Asparagine)/ $\alpha$-aminoisoverate(Valine) (A) and 5-methyl 2,4-dioxopyrimidine ( Thymine) (B)ligands have been analyzed. Formation constant of quaternary metal complexes and complexation equilibria at $30 \pm 1^{\circ} \mathrm{C}$ and at constant ionic strength $\left(I=0.1 \mathrm{M} \mathrm{NaNO}_{3}\right)$ have been explored potentiometrically. Formation of quaternary species in addition to hydroxyl, protonated, binary and ternary species have been reported. Overall formation constant have been evaluated using SCOGS computer program.Species distribution curves of complexes have been plotted as a function of $\mathrm{pH}$ to visualize the equlibria system and was refined using ORIGIN program.The metal ligand formation constant of $M A, M B, M A B$ and $M_{1} M_{2} A B$ type of complexes follow Irving William order. The order of stability constants of quaternary systems have been observed as: $\mathrm{Cu}-\mathrm{Ni}>$ $\mathrm{Cu}-\mathrm{Zn}>\mathrm{Cu}-\mathrm{Co}>\mathrm{Ni}-\mathrm{Zn}>\mathrm{Ni}-\mathrm{Co}>\mathrm{Co}-\mathrm{Zn}$. Solution structures of metal complexes with said ligands have been compared and discussed.

Keywords: Multinuclear complexes/SCOGS/Valine / Asparagine/ Thymine
\end{abstract}

\section{Introduction}

Transition metal adducts of nucleic acid are studied as probe of nucleic acid structure and function as artificial nuclease metallopharmaceuticals ${ }^{1}$, for the design and development of restrictive enzymes and DNA finger printing agents ${ }^{2}$. Considerable attention has been paid in recent year on the investigation of the complex forming properties of potentially bidentate and tridentates ligands ${ }^{3-6}$.The metal complexes of pyrimidine bases are of prime biological importance as a model of nucleic acids ion interactions ${ }^{7}$. Virtually all enzymes requires nucleoside as substrate in addition to a bivalent biologically important metal. Complexation of metal ions with amino acids , small peptides and their derivatives are of great significance as many complex metal-amino acids equilibria occuring in enzymatic processes ${ }^{8,9}$. Ternary and quaternary complexes ${ }^{10}$ are of significance in the study of bio- fluids particularly when hyper accumulated metal ions are present of physiological or pathological nature $^{10-11}$. In continuation to our recent communication ${ }^{12-16}$ on multi metal multi-ligand complexes, we report here the solution equilibria of $\mathrm{Cu}, \mathrm{Ni}, \mathrm{Co}$ and $\mathrm{Zn}$ metal ions with asparagines and thymine ligands using $\mathrm{PH}$ metry in aqueous medium. The species distribution with $\mathrm{pH}$ at different compositions, formation constants of binary, ternary, quaternary complexes and plausible equilibria for the formation of species are reported in this paper.

\section{Materials and Method}

All reagents used were of A.R. grade (sigma) .Solutions were prepared in double distilled $\mathrm{CO}_{2}$ free water. Metal Nitrate solutions were standardized by EDTA complexometric titration. ${ }^{12,13}$. Carbonate free $\mathrm{NaOH}$ solution was used as titrant ${ }^{14}$. $\mathrm{pH}$ measurements were made with century model $\mathrm{CP}$ 901-S pH meter using a special glass electrode (accuracy $\pm 0.01 \mathrm{pH}$ ) at $30 \pm 1^{\circ} \mathrm{C}$.

Binary $\mathrm{M}: \mathrm{A} / \mathrm{M}: \mathrm{B}$ (1:1),ternary $\mathrm{M}: \mathrm{A}: \mathrm{B}(1: 1: 1)$ and quaternary $\mathrm{M}_{1} \mathrm{M}_{2} \mathrm{AB}$ metal-ligand mixtures of following composition were prepared for titration, keeping total volume $50 \mathrm{ml}$ in each case .Strength of metal and ligand $=0.001 \mathrm{M}$ and $\mathrm{I}=0.1 \mathrm{M} \mathrm{NaNO}{ }_{3}$.

Solution A: $5 \mathrm{ml} \mathrm{NaNO}(1.0 \mathrm{M})+5 \mathrm{ml} \mathrm{HNO}_{3}(0.02 \mathrm{M})+$ water

Solution B: $5 \mathrm{ml} \mathrm{NaNO}_{3}(1.0 \mathrm{M})+5 \mathrm{ml} \mathrm{HNO}_{3}(0.02 \mathrm{M})+5 \mathrm{ml} \mathrm{A}(0.01 \mathrm{M})+$ water

Solution C: $5 \mathrm{ml} \mathrm{NaNO}(1.0 \mathrm{M})+5 \mathrm{ml} \mathrm{HNO}_{3}(0.02 \mathrm{M})+5 \mathrm{ml} \mathrm{A}(0.01 \mathrm{M})+5 \mathrm{ml} \mathrm{M}_{1}(\mathrm{II})(0.01 \mathrm{M})+$ water

Solution D: $5 \mathrm{ml} \mathrm{NaNO}(1.0 \mathrm{M})+5 \mathrm{ml} \mathrm{HNO}(0.02 \mathrm{M})+5 \mathrm{ml} \mathrm{A}(0.01 \mathrm{M})+5 \mathrm{ml} \mathrm{M}_{1}(\mathrm{II})(0.01 \mathrm{M})+5 \mathrm{ml} \mathrm{B}$ $(0.01 \mathrm{M})+$ water

Solution E : $5 \mathrm{ml} \mathrm{NaNO} 3(1.0 \mathrm{M})+5 \mathrm{ml} \mathrm{HNO}_{3}(0.02 \mathrm{M})+5 \mathrm{ml} \mathrm{A}(0.01 \mathrm{M})+5 \mathrm{ml} \mathrm{M}(\mathrm{II})(0.01 \mathrm{M})+5 \mathrm{ml}$ $\mathrm{B}(0.01 \mathrm{M})+5 \mathrm{ml} \mathrm{M}_{2}(\mathrm{II})(0.01 \mathrm{M})+$ water 
Where $\mathrm{M}_{1}$ (II) and $\mathrm{M}_{2}$ (II) are $\mathrm{Co} / \mathrm{Ni} / \mathrm{Cu}$ and $\mathrm{Zn}$

$\mathrm{A}=$ Primary ligand i.e. Asparagine

and $\mathrm{B}=$ Secondary ligand i.e. Thymine .

Each set of solution was then titrated against alkali $(\mathrm{NaOH})$. The $\mathrm{pH}$ meter reading with progressive addition of alkali to the titration mixtures were noted. The $\mathrm{pH}$ values were plotted against the volume of $\mathrm{NaOH}$ and the titration curves were obtained. The titrations were discontinued on the appearance of turbidity. Metal-ligand stability constants have been evaluated by SCOGS Computer program ${ }^{17}$. Values of constants were supplied to the computer as input data to obtain distribution curves of the complexes occurring at different $\mathrm{pH}$. Ionic product of water $\left(\mathrm{k}_{\mathrm{w}}\right)$ and activity coefficient of hydrogen ion under the experimental conditions were obtained from literature ${ }^{18}$.

\section{Results and Discussion}

\subsection{M1-M2 Valine Thymine (1:1:1:1) system:}

Metal complexation observed in Thymine is unusual due to absence of free lone pairs. Coordination in Thymine is reported to take place through ring nitrogen and carbonyl oxygen or from both the ring nitrogen making it bidentate ligand ${ }^{19}$.

U.V and Ultrasonic absorption studies indicate that in aqueous solution Thymine primarily exist in Lactum form, $\alpha$-hydroxyl and $\Upsilon$-hydroxyl group ionizes in alkaline medium corresponding to two $\mathrm{pK}$ values. It has been concluded that $\mathrm{Cu}(\mathrm{II})$ and $\mathrm{Co}(\mathrm{II})$ binds with thymine through ring nitrogen and carbonyl oxygen whereas in $\mathrm{Ni}$ (II) complex bonding occurs from both the ring nitrogen. In $\mathrm{Zn}$ (II) complex also bonding occurs from ring nitrogen and one carbonyl oxygen but one thymine coordinates at $\mathrm{C}_{2} \mathrm{O}$ position, while the other does at $\mathrm{C}_{4} \mathrm{O}$.

Based on the reported data, it may be concluded that Valine coordinate to metal ions as bidentate ligand through oxygen atom of carboxyate group $\left(\mathrm{COO}^{-}\right)$and nitrogen atom of amine group $\left(\mathrm{NH}_{2}\right)^{20}$. Due to presence of neutral side chain it can show three possible structures in different medium.<smiles>[R]C([2H])([NH3+])C(=O)O</smiles>

Acidic medium

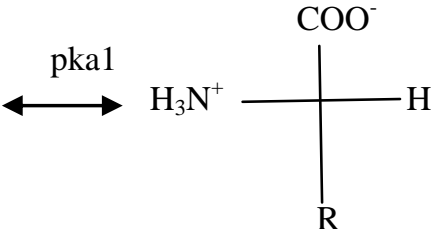

neutral medium

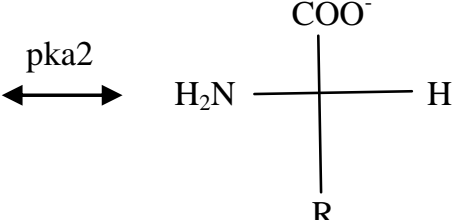

basic medium

The ionization constants have been determined using potentiometric technique and calculated using SCOGS computer program.

Complex formation has been assumed to take place according to following equilibrium:

$\mathrm{pM} 1+\mathrm{qM} 2+\mathrm{rA}+\mathrm{sB}+\mathrm{tOH} \leftrightarrow(\mathrm{M} 1) \mathrm{p}(\mathrm{M} 2) \mathrm{q}(\mathrm{A}) \mathrm{r}(\mathrm{B}) \mathrm{s}(\mathrm{OH}) \mathrm{t}$

$\beta$ pqrst $=[(\mathrm{M} 1) \mathrm{p}(\mathrm{M} 2) \mathrm{q}(\mathrm{A}) \mathrm{r}(\mathrm{B}) \mathrm{s}(\mathrm{OH}) \mathrm{t}] / \mathrm{M} 1] \mathrm{p}[\mathrm{M} 2] \mathrm{q}[\mathrm{A}] \mathrm{r}[\mathrm{B}] \mathrm{s}[\mathrm{OH}] \mathrm{t}$

Where $\mathrm{A}$ is primary ligand and $\mathrm{B}$ is secondary ligand.

Both ligands are present in decreasing order of concentration showing their involvement with both the metal ions understudy which also show declining pattern.

The formation of binary complexes of $\mathrm{Cu}$ (II) and $\mathrm{Ni}(\mathrm{II})$ with Valine takes place beyond $\mathrm{pH} \sim 8.0$ attaining its maximum at $\mathrm{pH} \sim 11.0$. $\mathrm{Zn}$ (II)-Valine and Co-Valine is formed in $\mathrm{pH}$ range $\sim 5.0$ to 9.0 and 5.5 to 10.0 respectively .Binary complexes of the type MB is almost absent in all the systems.

Formation equilibria of binary complexes may be assumed to occur as:

$\left[\mathrm{AH}_{2}\right]+\mathrm{M}^{2+} \leftrightarrow[\mathrm{M}(\mathrm{II})-\mathrm{A}]+2 \mathrm{H}^{+}$

$[\mathrm{AH}]^{-}+\mathrm{M}^{2+} \leftrightarrow[\mathrm{M}(\mathrm{II})-\mathrm{A}]+\mathrm{H}^{+}$

Mixed ligand complexes $[\mathrm{Cu}(\mathrm{II})-\mathrm{A}-\mathrm{BH}]^{-}$and $[\mathrm{Zn}(\mathrm{II})-\mathrm{A}-\mathrm{BH}]^{-}$are found to be major species in $\mathrm{Cu}(\mathrm{II})-\mathrm{Zn}$ (II) system. The formation of ternary complex species with $\mathrm{Co}^{2+}$ aq.), $\mathrm{Ni}^{2+}$ (aq.)and $\mathrm{Zn}^{2+}$ (aq.) ocurrs in the higher $\mathrm{pH}$ region $\sim 8.0-11$ formation of which incline with increase in $\mathrm{pH}$ and attains maximum concentration $(\approx 10 \%$ to30\%), according to the following equilibria:

$[\mathrm{AH}]^{-}+\mathrm{M}^{2+}+[\mathrm{BH}]^{-} \leftrightarrow[\mathrm{M}(\mathrm{II})-\mathrm{A}-\mathrm{BH}]^{-}+\mathrm{H}^{+}$
$[\mathrm{M}(\mathrm{II})-\mathrm{BH}]^{+}+{ }^{+}[\mathrm{AH}]^{-} \leftrightarrow[\mathrm{M}(\mathrm{II})-\mathrm{A}-\mathrm{BH}]^{-}+\mathrm{H}^{+}$
$[\mathrm{AH}]^{-}+\mathrm{M}^{2+}+[\mathrm{BH}]^{-} \leftrightarrow[\mathrm{M}(\mathrm{II})-\mathrm{A}-\mathrm{BH}]^{-}+\mathrm{H}^{+}$

Marked stabilization of the ternary relative to the binary complexes is reflected in the speciesdistribution plots,(fig. 3,4$)$ the ternary complexes occur in larger concentrations than the binary complexes at higher $\mathrm{pH}$ in each of the systems studied. 
As is revealed from the species distribution diagram, quaternary complexation starts at relatively lower $\mathrm{pH}$ i.e. $<5.0$. With the rise in $\mathrm{pH}$, its concentration gradually increases with the decrease in the concentration of protonated ligand species as well as free metal ions.

Multimetal - multiligand complex shows its maximum abundance $\approx 75 \%$ to $80 \%$ in the $\mathrm{pH}$ range 7 to $\sim 9.0$ and at still higher $\mathrm{pH}$ there is a gradual fall in its concentration.

For multinuclear system, the speciation curve indicates the formation of quaternary complex according to the following equilibrium:

$[\mathrm{AH}]^{-}+\mathrm{M}^{2+}+[\mathrm{BH}]^{-}+\mathrm{M} 2^{2+} \leftrightarrow[\mathrm{M} 1(\mathrm{II})-\mathrm{M} 2(\mathrm{II})-\mathrm{A}-\mathrm{B}]^{-}+2 \mathrm{H}^{+}$

The alternative equilibrium is also indicated as follows,

$[\mathrm{M} 1(\mathrm{II})-\mathrm{A}-\mathrm{BH}]^{-}+\mathrm{M}^{2+} \leftrightarrow[\mathrm{M} 1(\mathrm{II})-\mathrm{M} 2(\mathrm{II})-\mathrm{A}-\mathrm{B}]+\mathrm{H}^{+}$

$[\mathrm{M} 2(\mathrm{II})-\mathrm{A}-\mathrm{BH}]^{-}+\mathrm{M}^{2+} \leftrightarrow[\mathrm{M} 2(\mathrm{II})-\mathrm{M} 1(\mathrm{II})-\mathrm{A}-\mathrm{B}]+\mathrm{H}^{+}$

\subsection{M1-M2-Asparagine-Thymine system:}

Asparagine provides key side for $\mathrm{N}$-linked glycosylation.and exists as a Zwitter ionic species.<smiles>NC(=O)CC([NH3+])C(=O)[O-]</smiles>

For this reason it is appreciably soluble in water. The pronated form is titrated as a biprotic acid, obviously due to successive deprotonation of the $-\mathrm{COOH}$ and the $\mathrm{NH}_{3}{ }^{+}$moieties respectively.

Quaternary system observe presence of free metal ions, binary,ternary,quaternary and protonated species.

Concentration of free metal ions $\mathrm{M}_{1}{ }^{2+}$ (aq.) and $\mathrm{M}_{2}{ }^{2+}$ (aq.) and protonated ligand species follow declining pattern which shows their involvement in complex formation.

In comparison to MB binary complexes of MA are present in appreciable amount which starts at higher $\mathrm{pH}$ region. The complexation equilibria of binary complexes as follows:

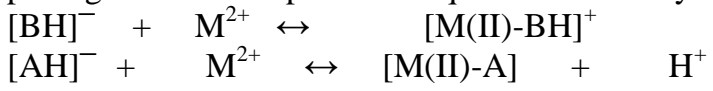

The concentration of binary complexes decrease probably due to formation of mixed-ligand complexes, which are found to be in appreciable concentration $(\sim 50 \%)$ according to following equilibria:

$$
[\mathrm{AH}]^{-}+\mathrm{M}^{2+}+[\mathrm{BH}]^{-} \leftrightarrow \quad[\mathrm{M}(\mathrm{II})-\mathrm{A}-\mathrm{BH}]^{-}+\mathrm{H}^{+}
$$

The alternative equilibrium are also indicated as follows:

$$
\begin{aligned}
& {[\mathrm{M}(\mathrm{II})-\mathrm{A}]+[\mathrm{BH}]^{-} \leftrightarrow[\mathrm{M}(\mathrm{II})-\mathrm{A}-\mathrm{BH}]^{-}} \\
& {[\mathrm{M}(\mathrm{II})-\mathrm{BH}]^{+}+[\mathrm{AH}]^{-} \leftrightarrow[\mathrm{M}(\mathrm{II})-\mathrm{A}-\mathrm{BH}]^{-}+\mathrm{H}^{+}} \\
& {[\mathrm{M}(\mathrm{II})-\mathrm{A}]+[\mathrm{BH}]^{-} \leftrightarrow[\mathrm{M}(\mathrm{II})-\mathrm{A}-\mathrm{BH}]^{-}}
\end{aligned}
$$

For multinuclear system, the species distribution curve indicates the formation of quaternary complex according to the following equilibrium:

$$
[\mathrm{AH}]^{-}+\mathrm{Ni}^{2+}+[\mathrm{BH}]^{-}+\mathrm{Zn}^{2+} \leftrightarrow[\mathrm{Ni}(\mathrm{II})-\mathrm{Zn}(\mathrm{II})-\mathrm{A}-\mathrm{B}]+2 \mathrm{H}^{+}
$$

The another form of equilibria may be represented as:

$[\mathrm{Ni}(\mathrm{II})-\mathrm{A}-\mathrm{BH}]^{-}+\mathrm{Zn}^{2+} \leftrightarrow[\mathrm{Ni}(\mathrm{II})-\mathrm{Zn}(\mathrm{II})-\mathrm{A}-\mathrm{B}]+\mathrm{H}^{+}$

Quaternary complexes occur in larger concentration than ternary complex, its maximum abundance is approximately greater than $90 \%$ in the $\mathrm{pH}$ range $\sim 6$ to 8 . However NiZnAB is found to be only $\sim 55 \%$. At $\mathrm{pH}>8.0$, there is a decline in the concentration of quaternary complex which may also be attributed to the formation of hydroxo species as the buffer region corresponding to the complexation equilibria has been found to be overlapping with the hydrolytic equilibria

Decline in concentration of multinuclear complex may be explained on the basis of formation of hydroxo species

$$
\begin{aligned}
& \mathrm{Ni}^{2+}+2 \mathrm{H}_{2} \mathrm{O} \leftrightarrow \mathrm{Ni}(\mathrm{II})(\mathrm{OH})_{2}+2 \mathrm{H}^{+} \\
& \mathrm{Co}^{2+}+\mathrm{H}_{2} \mathrm{O} \leftrightarrow \mathrm{Co}(\mathrm{II})(\mathrm{OH})^{+}+\mathrm{H}^{+} \\
& \mathrm{Co}^{2+}+2 \mathrm{H}_{2} \mathrm{O} \leftrightarrow \mathrm{Co}(\mathrm{II})(\mathrm{OH})_{2}+2 \mathrm{H}^{+}
\end{aligned}
$$

Refined values of binary and ternary constants are listed in table 1-2 which are in good agreement with those in literature

The overall stability constants of mixed-metal-mixed -ligand [Valine-Thyamine- $\mathrm{M}_{1}-\mathrm{M}_{2}$ ] systems have been found to follow the following order:

$\mathrm{Cu}-\mathrm{Ni}>\mathrm{Cu}-\mathrm{Zn}>\mathrm{Cu}-\mathrm{Co}>\mathrm{Ni}-\mathrm{Zn}>\mathrm{Ni}-\mathrm{Co}>\mathrm{Co}-\mathrm{Zn}$ 
The overall stability constants of mixed-metal mixed-ligand [Asparagine-Thyamine-- $\mathrm{M}_{1}(\mathrm{II})-\mathrm{M}_{2}(\mathrm{II})$ ] quaternary systems have been found to follow the following order:

$\mathrm{Cu}-\mathrm{Ni}>\mathrm{Cu}-\mathrm{Zn}>\mathrm{Cu}-\mathrm{Co}>\mathrm{Ni}-\mathrm{Zn}>\mathrm{Ni}-\mathrm{Co}>\mathrm{Co}-\mathrm{Zn}$

In aqueous solutions $\mathrm{Cu}^{2+}\left(\mathrm{d}^{9}\right)$ is tetragonally coordinated by six water molecules. Two axial water molecules lie at longer distances from the copper and are more labile than the four other water molecules.

The hydrated nickel ion presents regular octahedral configuration. Six equivalent sites of coordination are available unless a stronger ligand field provokes a tetragonal distortion and ultimately a square planar configuration. Hexacoordinated nickel is expected to form a greater number of isomeric complex species than copper, whose coordination geometry is usually dominated by the four "equatorial bonds".

The configuration of zinc can easily move from tetrahedral geometry to octahedral geometry depending upon the nature of bound ligands. Consequently the possible mixed species are in greater number than with copper.

Metals having higher $\log \beta$ value of metal-A complex will be the first to attach with ligand A,which further attaches to another ligand B to satisfy its coordination number. Coordination sites of ligands still left free will then are occupied by another metal ion. In all the binary, mixed ligand and mixed-metal mixed-ligand systems of present study possibilities for the binding of ligands with various metal ions taken understudy may be deduced.(Fig.1,2)

\section{References}

[1]. A. Sigel, H. Sigel,“ Probing of DNA by metal ion complexes of small molecules”Marcel Dekker Inc., New York, 1996, 33, 678: O Halloran TV, Science, 1993, 261, 715;

[2]. D. Magde, S. Croft, A. Lin, O. Mile, M. Wright, J. L. Sessler, J.Am. Chem.Soc. 1997,119, 2293

[3]. Duphem, J.K. Barton, “In Comprehensive Supramolecular Chemistry”, Ed.Lehn,J. M, Pergamon Press, New York, 1997, 5, 295: Tullis J.D., In metal DNA Chem,

[4]. J. Am. Chem. Soc., Symp series N 426, J. Am. Chem. Soc., Washington, 1989“

[5]. Metal ions in biological system’ ed. H. Sigel, Marcel Dekker, New York 1973, vol. 2

[6]. Inorganic Biochemistry ed. G.L Eichhorn,Elsevier, Amsterdam,1973, Vols.1\& 2.

[7]. L.G.Sillen and A. E. Martell, Special Pub. 'The Chemical Society London' 1964,No.17; suppl. 1,1971, No. 25.

[8]. S.T.Chow and C.A. McAvliffe,Prog.Inorg.Chem. 1975,19,51

[9]. H.M.Irving and R.J.P.Williams, Nature (London), 1948, 162,176

[10]. H.M.Irving and R.J.P.Williams, J.Chem.Soc. , 1953,3192

[11]. F.J.Welcher, "The Analytical uses of ethylene diaminetetraacetic acid" Van Nostrand, New York, 1957

[12]. I.M.Kolthoyy,B.B.Sandell, E.J.Meehan and A.Bruckenstein, "Quantitative Chemical analysis" McMillan, London, 1967(h.4)

[13]. G.Schwarzenbach and W.Biedermann, Helv. Chim. Acta ,1948, 31,331

[14]. V. Shankar, G.K. Mishra and V. Krishna; J. Indian, Chem. Soc, 2006

[15]. Divya Bartaria ,S.Sinha and V. Krishna, J.Indian Chem.Soc.2006,83,198

[16]. Divya Bartaria,Bipin K. Srivastava and V.Krishna, J.Indian Chem.Soc.2007,84,1199

[17]. Divya Bartaria,V.P Shukla and V.krishna J.Indian chem.soc Vol.86. Jan. 2009,9-13.

[18]. Krishna etal. Int.J. Res.chem.Enviroment.Vol 2.Issue 4 oct.2012(45-51).

[19]. I.G.Sayce,Talanta,1968,15,1397.

[20]. A. E. Martell and R. M. Smith; 'C Critical Stability Constants’ Plenum Press, New York, 1-6, (1974-1989)

[21]. Jansson M. J., Rec. Trav. Chim., 75, 1411(1956), 76, 827 (1957)

[22]. N.K. Fayad, Taghreed H. Al-Noor and F.H GhanimAdvances in Physics Theories and Applications ISSN 2224-719X (Paper) ISSN 2225-0638 (Online)Vol 9, 2012

1.Stability constant and other related constants of binary,ternary,and quaternary complexes of Asparagine (A) and Thymine(B) with different metal ions in aqueous solution at $30 \pm 1^{0} \mathrm{C}$ I=0.1M NaNO3

(i) Proton Ligand Formation Constant of Asparagine (A) and Thymine(B)

\begin{tabular}{|l|l|l|l|l|l|l|}
\hline $\begin{array}{l}\text { Proton-ligand } \\
\text { formation } \\
\text { constant (Log } \boldsymbol{\beta} \\
\text { pqrst) }\end{array}$ & $\mathbf{p}$ & $\mathbf{Q}$ & $\mathbf{r}$ & $\mathbf{S}$ & $\mathbf{t}$ & $\log \boldsymbol{\beta}$ \\
\hline H2A & 0 & 0 & 1 & 0 & -2 & 10.86 \\
\hline HA & 0 & 0 & 1 & 0 & -1 & 8.72 \\
\hline HB & 0 & 0 & 0 & 1 & -1 & 9.94 \\
\hline
\end{tabular}

(ii) Hydrolytic Constant of $\mathrm{M}^{+2}$ aq. ions

\begin{tabular}{|l|l|l|l|l|l|l|l|l|l|}
\hline $\begin{array}{l}\text { Hydrolytic constant of } \\
\begin{array}{l}\mathbf{M}^{+2} \mathbf{a q . ~ I o n s ~} \\
(\mathbf{L o g} \boldsymbol{\beta} \text { p0000t) }\end{array}\end{array}$ & $\mathbf{p}$ & $\mathbf{q}$ & $\mathbf{R}$ & $\mathbf{s}$ & $\mathbf{t}$ & $\mathbf{C O}$ & $\mathbf{N i}$ & $\mathbf{Z n}$ & $\mathbf{C u}$ \\
\hline $\mathbf{M}(\mathbf{O H})$ & 1 & 0 & 0 & 0 & 1 & -8.23 & -8.10 & -6.29 & -7.89 \\
\hline $\mathbf{M}(\mathbf{O H}) 2$ & 1 & 0 & 0 & 0 & 2 & - & - & 13.10 & -14.92 \\
\hline
\end{tabular}


Multiple Equilibria and Chemical distribution of some Bio metals with $\beta$-amide $\alpha$ -

(iii) Metal-ligand constants $\left(\left(\log \beta_{\text {oorst }}\right)\right.$ binary system

\begin{tabular}{|l|l|l|l|l|l|l|l|l|l|}
\hline \multicolumn{1}{|c}{ Complex } & $\mathbf{p}$ & $\mathbf{q}$ & $\mathbf{R}$ & $\mathbf{s}$ & $\mathbf{t}$ & $\mathbf{C O}$ & $\mathbf{N i}$ & $\mathbf{Z n}$ & $\mathbf{C u}$ \\
\hline MA & 1 & 0 & 1 & 0 & 0 & 4.00 & 4.30 & 6.77 & 8.32 \\
\hline MB & 1 & 0 & 0 & 1 & 0 & 6.34 & 7.06 & 8.20 & 8.83 \\
\hline
\end{tabular}

(iv) Metal -ligand constants $((\log \beta$ porst $)$ ternary system

\begin{tabular}{|l|l|l|l|l|l|l|l|l|l|}
\hline Complex & $\mathbf{p}$ & $\mathbf{q}$ & $\mathbf{R}$ & $\mathbf{s}$ & $\mathbf{t}$ & $\mathbf{C O}$ & $\mathbf{N i}$ & $\mathbf{Z n}$ & $\mathbf{C u}$ \\
\hline MAB & 1 & 0 & 1 & 1 & 0 & 11.51 & 12.71 & 14.51 & 12.08 \\
\hline
\end{tabular}

(v) Metal -ligand constants $\left(\left(\log \beta_{\text {pqrst }}\right)\right.$ quaternary system.

\begin{tabular}{|l|l|l|l|l|l|l|l|l|}
\hline Complex & $\mathbf{p}$ & $\mathbf{q}$ & $\mathbf{R}$ & $\mathbf{s}$ & $\mathbf{t}$ & $\mathbf{C U}-\mathbf{N i}$ & $\mathbf{C u}-\mathbf{Z n}$ & $\mathbf{C u}-\mathbf{C O}$ \\
\hline & 1 & 1 & 1 & 1 & 0 & 22.66 & 20.85 & \\
& & & & & & & Ni-Zn & \\
\hline $\mathbf{M}_{\mathbf{1}} \mathbf{M}_{\mathbf{2}} \mathbf{A B}$ & & & & & & & Ni-Co & Zn-Co \\
\hline & & & & & & & 20.11 & \\
& & & & & & 20.39 & & 17.78 \\
\hline
\end{tabular}

2. Stability constant and other related constants of binary,ternary,and quaternary complexes of Valine(A)and Thyamine(B) with different metal ions in aqueous solution at $30 \pm 1^{0} \mathrm{C} I=0.1 \mathrm{M} N \mathrm{NaNO}$

(i) Proton Ligand Formation Constant of Asparagine (A) and Thymine(B)

\begin{tabular}{|l|l|l|l|l|l|l|}
\hline $\begin{array}{l}\text { Proton-ligand formation } \\
\text { constant (Log } \boldsymbol{\beta} \text { pqrst) }\end{array}$ & $\mathbf{p}$ & $\mathbf{Q}$ & $\mathbf{r}$ & $\mathbf{S}$ & $\mathbf{t}$ & $\log \boldsymbol{\beta}$ \\
\hline H2A & 0 & 0 & 1 & 0 & -2 & 11.75 \\
\hline HA & 0 & 0 & 1 & 0 & -1 & 9.95 \\
\hline HB & 0 & 0 & 0 & 1 & -1 & 9.94 \\
\hline
\end{tabular}

(ii) Metal-ligand constants $\left(\left(\log \beta_{\text {oorst }}\right)\right.$ binary system

\begin{tabular}{|l|l|l|l|l|l|l|l|l|l|}
\hline Complex & $\mathbf{p}$ & $\mathbf{q}$ & $\mathbf{R}$ & $\mathbf{s}$ & $\mathbf{t}$ & $\mathbf{C O}$ & $\mathbf{N i}$ & $\mathbf{Z n}$ & $\mathbf{C u}$ \\
\hline MA & 1 & 0 & 1 & 0 & 0 & 4.45 & 5.42 & 4.86 & 8.11 \\
\hline MB & 1 & 0 & 0 & 1 & 0 & 6.34 & 7.06 & 8.20 & 8.83 \\
\hline
\end{tabular}

(iii) Metal -ligand constants $((\log \beta$ porst $)$ ternary system

\begin{tabular}{|l|l|l|l|l|l|l|l|l|l|}
\hline Complex & $\mathbf{p}$ & $\mathbf{q}$ & $\mathbf{r}$ & $\mathbf{s}$ & $\mathbf{t}$ & $\mathbf{C O}$ & $\mathbf{N i}$ & $\mathbf{Z n}$ & $\mathbf{C u}$ \\
\hline MAB & 1 & 0 & 1 & 1 & 0 & 11.31 & 12.81 & 11.62 & 15.33 \\
\hline
\end{tabular}

(iv) Metal -ligand constants $\left(\left(\log \beta_{\text {pqrst }}\right)\right.$ quaternary system.

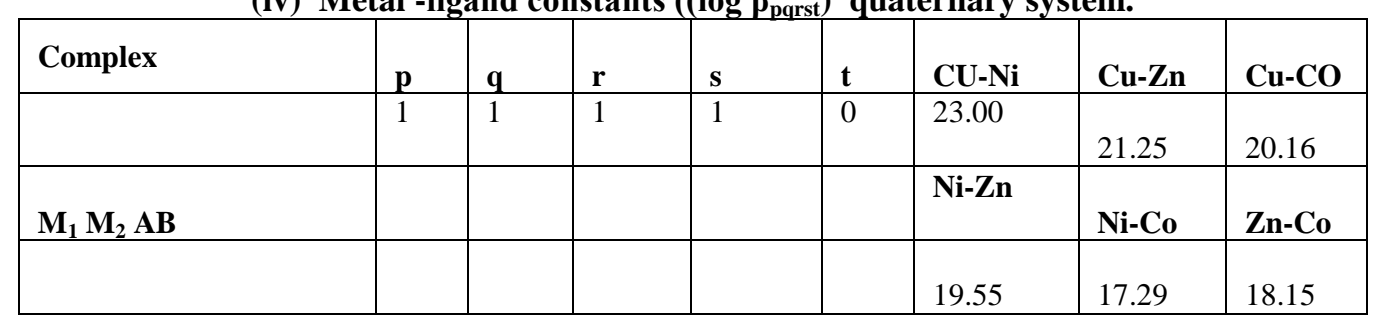




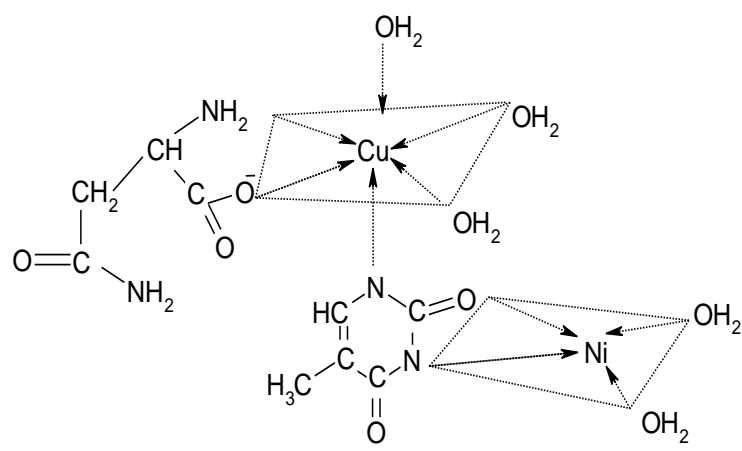

Fig.1. Proposed structure of Quaternary Cu(II)-Ni(II)-Asparagine-Thymine.

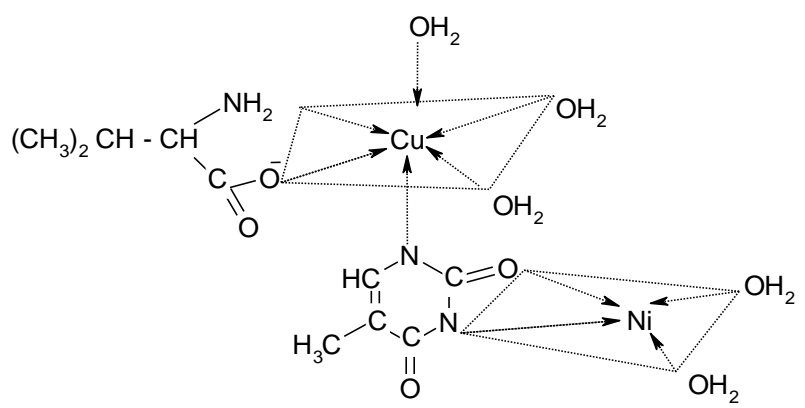

Fig.2. Proposed structure of Quaternary $\mathrm{Cu}(\mathrm{II})-\mathrm{Ni}(\mathrm{II})-$ Valine-Thymine.

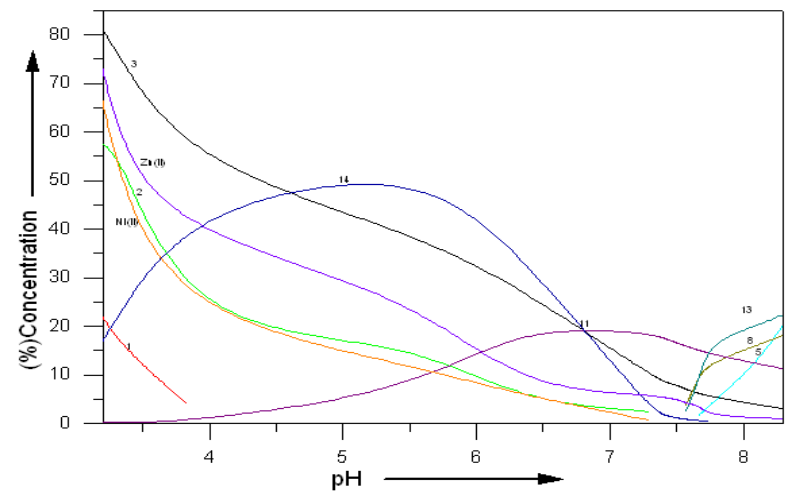

Fig.3- Distribution Curves of 1:1:1:1 Ni(II)-Zn(II)-Asparagine-Thymine system; (I) $\mathrm{AH}_{2}$ (2) $\mathrm{AH}$ (3) $\mathrm{BH}$ (4) $\mathrm{Ni}(\mathrm{OH})^{+}(5) \mathrm{Ni}(\mathrm{OH})_{2}(6) \mathrm{Zn}(\mathrm{OH})^{+}(7) \mathrm{Zn}(\mathrm{OH})_{2}$ (8) $\mathrm{NiA}$ (9) $\mathrm{NiB}$ (10) $\mathrm{ZnA}$ (11) $\mathrm{ZnB}$ (12) $\mathrm{NiAB}$ (13) ZnAB (14) NiZnAB

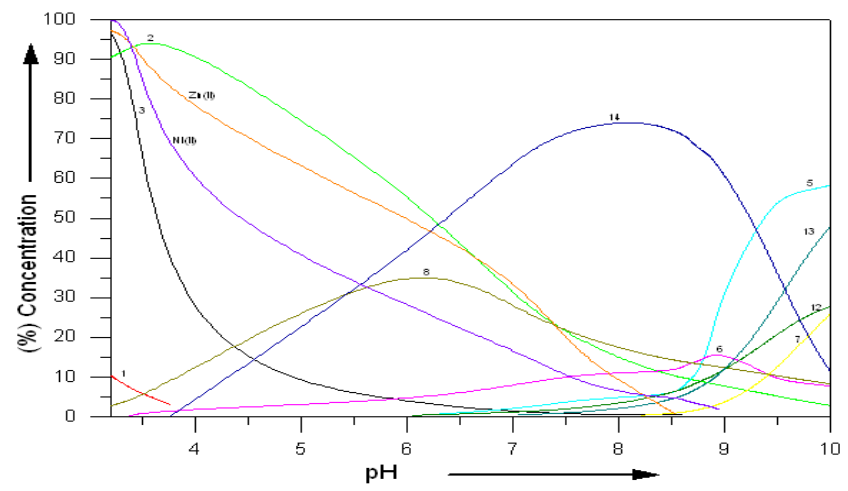

Fig.4- Distribution Curves of 1:1:1:1 Ni(II)-Co(II)-Valine-Thymine system; (I) $\mathrm{AH}_{2}$ (2) $\mathrm{AH}$ (3) $\mathrm{BH}$ (4) $\mathrm{Ni}(\mathrm{OH})^{+}(5) \mathrm{Ni}(\mathrm{OH})_{2}(6) \mathrm{Co}(\mathrm{OH})^{+}(7) \mathrm{Co}(\mathrm{OH})_{2}(8) \mathrm{NiA}(9) \mathrm{NiB}(10) \mathrm{CoA}(11) \mathrm{CoB}(12) \mathrm{NiAB}(13) \mathrm{CoAB}$ (14) NiCoAB 